\title{
Homogenization of Fibers Reinforced Composite Materials for Simulation Analysis
}

Lukáš Smetanka ${ }^{1}$, Juraj Gerlici ${ }^{1}$, Tomáš Lack ${ }^{1}$, Zoran Pelagić ${ }^{1}$

${ }^{1}$ Faculty of Mechanical Engineering, University of Žilina, Univerzitná , 01026 Žilina, Slovak Republic, , e-mail: lukas.smetanka@fstroj.uniza.sk,juraj.gerlici@fstroj.uniza.sk,tomas.lack@fstroj.uniza.sk, zoran.pelagic@ fstroj.uniza.sk

The article is aimed to the development of homogenization procedures for fibers reinforced composite materials. The development of these procedures during the homogenization was performed by using a representative volume element (RVE). Two RVE versions were developed, hexagonal and square fiber arrangement. Both modules are automated and have been developed in the Python programming language with connection to FEM software Abaqus, which serves as a solver, and post processor. Afterwards the assembled modules follow homogenization of particular composite structures, which results are in a comparison with result gained from other homogenization methods (analytical methods for homogenization of composite materials) are processed into tables.

Keywords: homogenization, representative volume element (RVE), composite materials, finite element method

\section{Acknowledgement}

The work was supported by the Scientific Grant Agency of the Ministry of Education of the Slovak Republic and the Slovak Academy of Sciences in project No. 1/0347/12: "Railway wheel tread profile wear research under the rail vehicle in operation conditions simulation on the test bench", project No. 1/0383/12: "The rail vehicle running properties research with the help of a computer simulation." and the project No. APVV-0842-11: "Equivalent railway operation load simulator on the roller rig".

\section{References}

[1] LAŠ, V. (2007). Mechanika kompozitných materiálu. Plzeň. Západočeská univerzita v Plzni, ISBN 80-7043-273X, 2007, p. 158.

[2] VRBKA, J. (2008). Mechanika kompozitu. Brno. Vysoké učení technické v Brne, ISBN 80-7043-273-X, 2008, p. 94.

[3] RIECKY, D. (2012). Aplikácia bezsietových metód pre analýzu kompozitných dosiek vystužených jednosmernými vláknami. Dizertačná práca. Žilina. Žilinská univerzita v Žiline, 2012, p. 138.

[4] SMETANKA, L. (2014). Vývoj metód pre homogenizáciu kompozitných materiálov vystužených vláknami. Diplomová práca, Žilinská univerzita v Žiline, Strojníka fakulta, 2014, p. 67.

[5] BARBERO, J. (2013). Finite Element Analysis of Composite Materials Using Abaqus. Boca Raton. CRC Press, ISBN 978-1-4665-1661-8, 2013, p. 413.

[6] SVOBODA, M., SKOČILAS, J., SOUKUP, J. (2011) Analysis of vertical vibration of mechanical system. In: Dynamical systems. Analytical /Numerical Methods, Stability, Bifurcation and Chaos". pp. 261 - 268. Department of Automation and Biomechanics. Polytechnika Lodž., 2011.

[7] PURI, G. (2011). Python Scripts for Abaqus. Learn by Example (book prewiev).[online]. [cit.2014.03.15] Dostupné na internete. http.//www.abaquspython.com/downloads.html

[8] ŽMINDÁK, M., RIECKY, D., SOUKUP, J. (2010). Failure of Composites with Short Fibres. Communications, vol. 12, no. 4, ISSN 13354205, 2010, pp. 33-39.

[9] KORMANIKOVÁ, E., RIECKY, D., ŽMINDÁK, M. (2011). Strength of composites with fibers. In: Murín, J. Kompiš, V., Kutiš, V., eds. Computational Modelling and Advanced Simulations, Springer Science + Business Media B.V., ISBN 978-94-007-0316-2, 2011, pp. 167-183.

[10]ŽMINDÁK, M., NOVÁK, P. (2009). Particle Interactions in Composites Reinforced by Fibre and Spherical Inclusions. Communications, vol. 11, no. 2, ISSN 1335-4205, 2009, pp.13-18.

[11]ŽMINDÁK, M., PELAGIĆ, Z. (2012). FEM simulation of high velocity shock waves in fiber reinforced composites. In: Proceedings of the 18th International conference Engineering mechanics, Svratka, 14.-17.05. 2012, 1631-1642, ISBN 978-80-86246-40-6 (CD ROM)

[12]ŽMINDÁK, M., DUDINSKÝ, M., PELAGIĆ, Z. (2013) Micro-mechanical Analysis of Composites Reinforced with Discontinuous Fibers with Large Aspect Ratio/ In: Applied Mechanics and Materials, Volume 420, doi. 10.4028/www.scientific.net/AMM, 420.269, 2013, pp. 269-275.

[13] WEISS, V., STRIHAVKOVA, E. (2012). Influence of the homogenization annealing on microstructure and mechanical properties of AlZn5,5Mg2,5Cu1,5 alloy/ In: Manufacturing Technology, December 2012, Vol.12, No.13, ISSN 1213-2489. 